\title{
Deep-seated bedrock landslides and submarine canyon evolution in an active tectonic margin: Cook Strait, New Zealand.
}

\author{
Aaron Micallef ${ }^{1,2}$, Joshu J. Mountjoy ${ }^{3}$, Miquel Canals ${ }^{1}$ and Galderic Lastras ${ }^{1}$ \\ 1. GRC Geociències Marines, Universitat de Barcelona, E-08028, Spain. +34 934021369, \\ micallefaaron@ub.edu. \\ 2. University of Malta, Msida, MSD 2080, Malta. \\ 3. National Institute of Water and Atmospheric Research, Private Bag 14901, Wellington. New \\ Zealand.
}

\begin{abstract}
The Cook Strait sector of the Hikurangi subduction margin, off south-east central New Zealand, is dominated by a multi-branched canyon system where landslides are widespread. The objective of this study is to determine the character, origin, and influence of these landslides on the evolution of the canyon system. Multibeam bathymetry covering seven submarine canyons is utilised to characterise landslides' spatial distribution, morphological attributes and area-frequency characteristics. We demonstrate that mass movements within the Cook Strait canyons consist of spatially dense, predominantly retrogressive, small, deep-seated, translational bedrock landslides occurring in Late Cenozoic sequences. These landslides affect up to a quarter of the canyoned area. Concentration of landslides in the shallow canyon reaches (down to $800 \mathrm{~m}$ ) is attributed to the influence of oceanographic processes originating on the continental shelf such as tidegenerated currents, dense shelf water cascading and internal waves. Canyon incision and wall undercutting, locally favoured by underlying lithological control, are proposed as major landslide drivers in Cook Strait. Ground motion during regional earthquakes is considered a secondary cause. Retrogressive landslides are responsible for canyon widening and wall retreat, cross-sectional asymmetry, preconditioning for additional failure, destabilisation of adjacent slopes and delivery of sediment into canyon floors.
\end{abstract}

Keywords: Bedrock landslide, submarine canyon, morphometric analysis, Cook Strait.

\section{Introduction}

The Hikurangi margin is a transpressional subduction arc located off New Zealand's North Island. The Cook Strait (CS) sector is located in the southern Hikurangi margin and is traversed by a series of active thrust and strike-slip faults (Barnes and Audru 1999). The CS sector also hosts the largest canyon system in the whole margin, where 
landslide scars are widespread (Fig. 1). High-resolution multibeam bathymetric data from the CS sector offer an excellent opportunity to investigate the regional impact of landslides on canyon morphology and evolution in an active margin. This is important because active tectonic margins comprise about a third of global continental margins, and the influence of active tectonics provides a distinctive context for canyon evolution that has not been fully explored. Landsliding is receiving increasing consideration as a key factor in canyon formation (e.g. Sultan et al. 2007), although studies relating bedrock landslides to canyons evolution are few and the nature and frequency of the these processes are poorly constrained. The objective of this study is therefore to determine the character and origin of bedrock landsliding, and its influence on the long-term evolution of the CS submarine canyon system.

\section{Data sets and methodology}

This study is based on $8400 \mathrm{~km}^{2}$ of multibeam bathymetry collected by RV Tangaroa between 2002 and 2005 using a hull-mounted Simrad EM300 multibeam system operating at a $30 \mathrm{kHz}$ frequency and a POS/MV system with differential GPS. The navigational accuracy is $\pm 5 \mathrm{~m}$ and vertical accuracy in $1000 \mathrm{~m}$ water depth is $\pm 2 \mathrm{~m}$. The data were gridded to a $10 \mathrm{~m} \times 10 \mathrm{~m}$ bin size.

Landslides within the CS canyon system have been identified and mapped on the basis of morphology. Standard morphometric attributes were extracted from the bathymetric data set using Geographic Information System (GIS) software. A geomorphometric map and an automated topographic classification (using the standard deviation of slope gradient) were also generated using techniques described in Micallef et al. (2007). These were carried out to delineate the boundaries of landslides and segment the seabed according to roughness. Our method of landslide extraction is limited by the difficulty of mapping old, shallow-seated landslides and overlapping failures accurately.

Once the landslide boundaries were determined, measurements of specific mor-

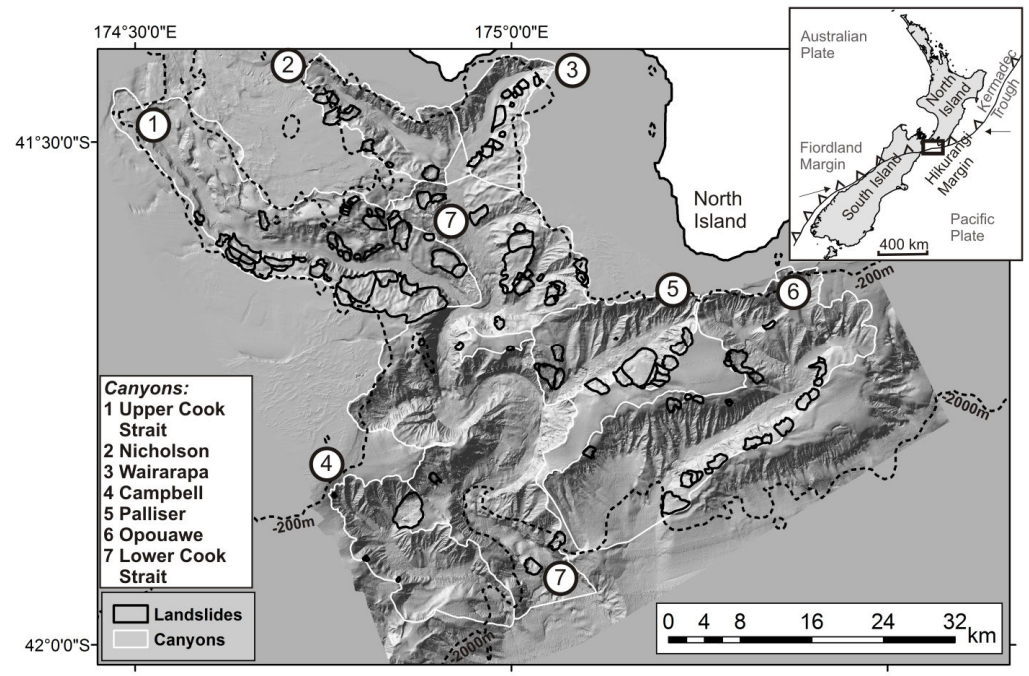

Fig. 1. Location (inset) and shaded relief map of Cook Strait submarine canyon system in the southern Hikurangi margin. The mapped landslides are outlined in solid black. Dotted black lines denote bathymetric contours. 
phometric attributes of each individual landslide were made. These included: i.Bathymetric depth: The depth of the centroid of each landslide; ii. Headwall length: The terminations of a headwall are defined by the zone where material has moved perpendicularly to the escarpment; iii. Headwall height: Difference in elevation between top and foot of headwall; iv. Landslide direction: Predominant direction of material mobilisation; v. Area: Total area of the headwall, slide scar and deposit; vi. Volume: A smooth surface was interpolated from the polygon that defines the boundary of each landslide scar and then subtracted from the original bathymetry. The method and associated assumptions are detailed in Chaytor et al. (2009).

For headwall height, several measurements were made from adjacent cross-sections in order to calculate a mean value. Where features were not prominent, the steepest section of the features was considered.

\section{Results}

\subsection{Submarine canyon morphology}

Seven canyons dissect the continental slope of the CS sector, from the continental shelf down to the Hikurangi Channel at a depth of $2500 \mathrm{~m}$ (Fig. 1). Nicholson, Wairarapa, Upper Cook Strait and the shallower part of the Lower Cook Strait Canyons are incised in Late Cenozoic sedimentary sequences of consolidated and gently dipping mudstone, siltstone or sandstone (Mountjoy et al. 2009). The northern walls of Nicholson and Wairarapa canyons comprise Torlesse Greywacke Mesozoic basement, which consists of well-indurated and slightly metamorphosed mudstones and silty sandstones (Barnes and Audru 1999). Palliser, Opouawe, Campbell and the deeper part of Lower Cook Strait Canyons are incised in Neogene turbidite sequences (Uruski 2010). The morphological characteristics of each canyon are presented in Table 1. The crosssectional shape of the canyons is generally V-shaped, with a gently sloping canyon floor that can be up to $2.5 \mathrm{~km}$ wide. The walls can locally reach slope gradients in excess of $30^{\circ}$; they are eroded by linear and dendritic gullies (Micallef and Mountjoy 2011) and landslides.

\subsection{Landslides}

\subsubsection{Morphological characteristics}

There are at least 141 landslides on the walls of the CS canyons. They are characterised by well-defined arcuate headwalls, sub-parallel sidewalls and a near-planar, smooth failure surface (Figs. 1, 2a). The direction of landslide movement is predominantly perpendicular or quasi-perpendicular to that of the canyon thalweg (Fig. 3d). Several canyon walls display up to three levels of landslide retrogression (Fig. 2a). Numerous land- 
slide scars are perched above high and steep overhangs (Fig. 2a); a few landslides are located upslope of gully systems (Fig. 2b).

\begin{tabular}{|l|c|c|c|c|c|c|c|c|}
\hline Canyon morphology & Cm & UCS & LCS & Nc & Op & Pr & Wp & \\
\hline Length $(\mathrm{km})$ & 27.7 & 45.0 & 70.0 & 19.5 & 39.5 & 20.9 & 14.7 & \\
\hline Maximum width $(\mathrm{km})$ & 12.0 & 12.7 & 14.8 & 8.9 & 13.7 & 11.9 & 10.7 & \\
\hline Head depth $(\mathrm{m})$ & 310 & 150 & 110 & 110 & 390 & 90 & 45 & \multirow{2}{*}{-} \\
\hline Maximum incision depth $(\mathrm{m})$ & 650 & 575 & 750 & 500 & 750 & 650 & 500 & \\
\hline Depth from canyon head to mouth $(\mathrm{m})$ & 2070 & 900 & 1800 & 590 & 1730 & 1450 & 630 & \\
\hline Thalweg mean slope gradient $\left({ }^{\circ}\right)$ & 4.27 & 1.35 & 1.39 & 1.73 & 2.50 & 3.97 & 2.30 & \\
\hline General orientation & NW-SE & NW-SE & N-S & NW-SE & NE-SW & NE-SW & NE-SW & \\
\hline Area $\left(\mathrm{km}^{2}\right)$ & 182 & 385 & 683 & 112 & 465 & 166 & 99 & \\
\hline Landslide morphology & Cm & UCS & LCS & Nc & Op & Pr & Wp & All \\
\hline Landslides $(n)$ & 5 & 45 & 27 & 8 & 28 & 16 & 12 & \multirow{2}{*}{141} \\
\hline Total landslide area $\left(\mathrm{km}^{2}\right)$ & 9.76 & 88.75 & 78.31 & 11.00 & 30.94 & 32.32 & 9.28 & 260.35 \\
\hline Median slide area $\left(\mathrm{km}^{2}\right)$ & 0.13 & 0.72 & 0.91 & 1.52 & 0.76 & 1.65 & 0.65 & 0.82 \\
\hline Landslides:canyon area $\left(\mathrm{km}^{-2}\right)$ & 0.03 & 0.12 & 0.04 & 0.07 & 0.06 & 0.10 & 0.12 & 0.07 \\
\hline Mean landslide area:canyon area $(\%)$ & 5.36 & 23.05 & 11.47 & 9.81 & 6.65 & 19.48 & 9.33 & 12.44 \\
\hline Total landslide volume $\left(\mathrm{km}^{3}\right)$ & 0.66 & 1.71 & 1.28 & 0.21 & 0.45 & 0.77 & 0.13 & 5.22 \\
\hline Median landslide volume $\left(\mathrm{km}^{3}\right)$ & 0.001 & 0.011 & 0.014 & 0.022 & 0.081 & 0.042 & 0.010 & 0.013 \\
\hline Median headwall length $(\mathrm{m})$ & 344 & 1156 & 1489 & 1472 & 1217 & 1363 & 852 & 1199 \\
\hline Median headwall height $(\mathrm{m})$ & 62 & 73 & 78 & 67 & 63 & 108 & 67 & 74 \\
\hline
\end{tabular}

Table 1. Canyon and landslide morphological information. $\mathrm{Cm}=$ Campbell; UCS $=$ Upper Cook Strait; LCS $=$ Lower Cook Strait; $\mathrm{Nc}=$ Nicholson; $\mathrm{Op}=$ Opouawe; $\mathrm{Pr}=$ Palliser; $\mathrm{Wp}=$ Wairarapa.

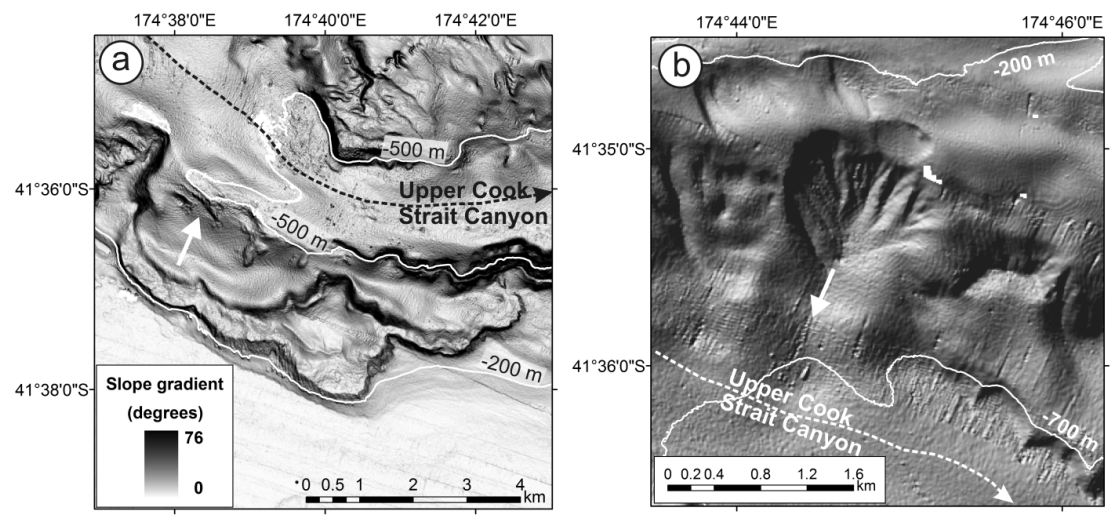

Fig. 2. (a) Slope gradient map of the south-western wall of Upper Cook Strait Canyon showing perched, coalescing landslide scars with well-defined arcuate headwalls and a smooth failure surface. (b) Shaded relief map, illuminated from the NW, showing a landslide scar located on the north-eastern wall of Upper Cook Strait Canyon that has been incised by a gully system. Loss of support at the head of the gully system has caused a small landslide to occur. White arrows indicate direction of movement of landslide material. Canyon axes are marked by dotted lines. 
The morphometric characteristics of the mapped landslides are listed in Table 1. The landslides' dimensions range across 3 orders of magnitude $\left(0.03-29.56 \mathrm{~km}^{2}\right.$ for area and $0.0005-0.88 \mathrm{~km}^{3}$ for volume). The landslides are predominantly small-scale, as implied by a log-normal area-frequency distribution (Fig. 3c), with a median slide area and volume of $0.82 \mathrm{~km}^{2}$ and $0.013 \mathrm{~km}^{3}$, respectively. The median headwall height, at $74 \mathrm{~m}$, is relatively high for such small landslides. A very good correlation is obtained when plotting landslide area with volume $\left(R^{2}=0.9\right)$ (Fig. 3a). The amount of work carried out by landslides, which is an expression of the amount of material moved by a geomorphic event (Wolman and Miller 1960), has been estimated by multiplying the area of the landslide and frequency for each bin of the area-frequency distribution (Fig. 3c). The plot shows that the majority of the work is carried out by the smaller landslides.
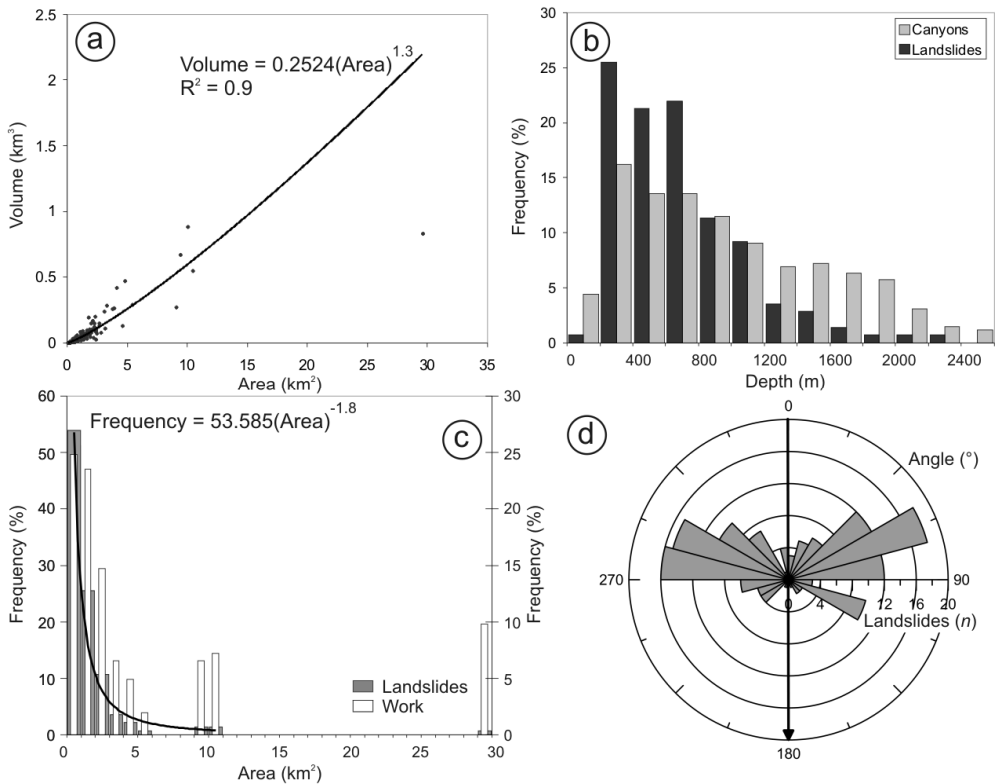

Fig. 3. (a) Plot of mapped landslide area vs. volume; (b) Histogram of water depth of the seabed within canyons, compared with a histogram of the water depth of the centroid of each mapped landslide; (c) Histogram and inverse power trend line for the area-frequency of the mapped landslides, and histogram of work carried out by the landslides; (d) Rose diagram of landslide movement vectors in respect to canyon thalweg direction (black arrow).

\subsubsection{Distribution}

The landslides are located across the entire depth range covered by the canyons, although $75 \%$ of landslides occur in the shallow canyon reaches (200-800 m) (Fig. 3b). The majority of the landslides originate in Late Cenozoic sequences. Landslide deposits are either located at the base of the failure scar or they are absent from both slide scar and canyon thalweg. Landslide deposits are only occasionally visible on the canyon floor in the form of blocks (e.g. Palliser Canyon). The highest landslide area:canyon area fractions are observed in the canyons with the shallowest heads (Table 1). Landslides cluster along the lower to middle canyon wall sections and they tend to preferen- 
tially occur on one side of each canyon (Fig. 4). The slope gradients of canyon walls where landslides occur are gentler than those without landslides, which give rise to canyon wall asymmetry in cross-section (Fig. 4).
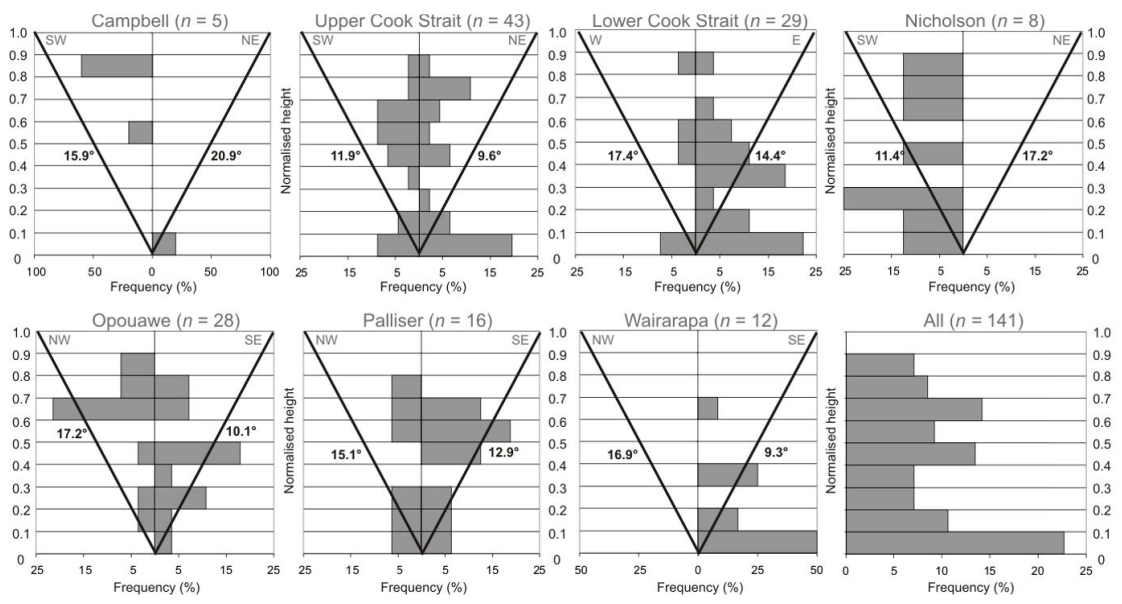

Fig. 4. Histograms of normalised landslide height above canyon floor for all canyon walls. Also shown is the mean slope gradient estimated for each canyon wall.

\section{Discussion and Conclusions}

\subsection{Nature of landslides}

Seismic reflection profiles presented in Mountjoy et al. (2009) demonstrate that landsliding within the CS submarine canyons is stratigraphically-controlled. The failure planes tend to follow stratification, with weak layers within the bedded marine sequences facilitating slope failure. The stratigraphic control is also revealed in the estimated mean headwall height, which is comparable for all canyons but Palliser (Table 1). By combining the information in these profiles with our observations of slide scar morphology and distribution, we interpret the landslides within the CS canyons as deepseated, translational, bedrock landslides occurring in Late Cenozoic to Pleistocene sequences. Furthermore, the power law relationship between landslide area and volume is characterised by an exponent of 1.3 (Fig. 3a), which is similar to that obtained by ten Brink et al. (2006) for slides in layered limestones, and higher than that obtained by Issler et al. (2005) for clay-rich debris flows. This exponent indicates deeper excavation of material by the larger slope failures in the CS canyons. This contrasts with landslides in the Atlantic Ocean, where volume increases almost linearly with area, indicating a relatively constant evacuation depth (e.g. Chaytor et al. 2009; Issler et al. 2005). 


\subsection{Causes of landslides}

We propose two main causes of canyon landslides:

a. Canyon incision and wall undercutting. Landslide scars are generally concentrated in the lower half of the canyon walls. The direction of the majority of slides is quasi-perpendicular to the canyon thalweg (Figure 3d). The presence of perched slides attests to periods of thalweg excavation. Retrogression is observed at a number of places in the form of small landslides stepping upslope from larger landslides on the canyon wall. Canyon incision and wall undercutting are therefore proposed as the first order driver of landslides in the CS canyons. The larger landslides occur where scouring of the canyon floor undermines and steepens the base of the canyon wall, whereas the upper, smaller slides occur due to loss of support; this is comparable to the origin of terrestrial bedrock landslides in the physical model of Densmore et al. (1997). In spite of the numerous canyon wall failures, we notice a general absence of landslide deposits within the canyon axes. This supports the hypothesis that canyons were active at the same time as the canyon walls were failing or shortly after, and that material was removed from the canyon bed. Proof that this activity may be recent can be found in cores from Nicholson and Upper Cook Strait Canyons, which show repeated sandy turbidites and a lack of any large accumulation of hemipelagic sequences on the canyon floor (Mountjoy et al. 2009). Few landslides are located in Campbell Canyon (Table 1); this observation emphasises the importance of canyon downcutting because Campbell Canyon is an abandoned, infilled tributary of the Lower Cook Strait Canyon (Mountjoy et al. 2009). Repeated mass movements across the canyon walls may also account for the width of the canyon floor, which cannot be explained by canyon incision alone. Canyon cross-sectional asymmetry (Fig. 4), on the other hand, may be explained by flows within the canyon thalweg impinging on the north-facing canyon walls due to gravity, giving rise to landslide clustering across these slopes. Cross-sectional asymmetry in Palliser and Opouwae canyons, on the other hand, may be due to the presence of tectonic ridges, the forelimbs of which can be up to two times steeper than the backlimbs.

b. Earthquakes. Some landslides are located in the upper half of canyon walls with no connection to canyon thalwegs (Fig. 4). Landslide scar distribution occasionally correlates with active faults, which act as significant earthquake sources (e.g. Christchurch February 2011 M6.3 earthquake). Ground motion during regional earthquakes and its influence on steep, undercut canyon walls is proposed as a second major cause of landslides. The role of earthquakes in causing slope failure is believed to be important in the CS canyons because of a high concentration of active faults and the modelled frequent occurrence of strong earthquake-generated ground motion (Stirling et al. 2002). We suggest that failures occur as either co-seismic events, due to deformation of slopes during ground shaking, or through generation of excess pore pressures in high permeability horizons due to cycling loading (Mountjoy et al. 2009).

Uplift and over-steepening of canyon walls due to active anticlinal folding may constitute an additional cause of landslides, but this would only account for landslide occurrence in Palliser and Opouawe canyons.

\subsection{Spatial distribution of landslides}

Bedrock landslides can be found in all the canyons. The concentration of landslides in the shallow, shelf-incised canyon reaches (Fig. 3b) implies that there is a dominating influence on the depth zonation of failures. One possible reason for this zonation is that 
canyon incision is driven by an oceanographic process originating in the shelf area. We assume that such a process would influence the shallower canyons the most (Nicholson, Wairarapa, Upper Cook Strait, shallower Lower Cook Strait Canyons), and it could explain why landslides cluster in the lower half of these canyons' walls (Fig. 4). A possible candidate for such an oceanographic process is tide-generated currents and related sediment input. Tides may play a role in generating a strong, recurring and directionally stable flow that can transport sediment and deepen the canyon. The signal of such a flow has been identified at depths down to $1000 \mathrm{~m}$ (Law et al. 2010). Other potential candidates include cascading dense water (Micallef and Mountjoy 2011) and internal waves, although these oceanographic processes still need to be documented in CS. At present, large scale ocean currents and fluvial sediment discharge are not considered influential in the study area (Chiswell 2000; Hicks and Shankar 2003), although the latter should have been more significant during glacial lowstands. In comparison to the shallower canyons, the deeper canyons (deeper Lower Cook Strait, Campbell, Palliser and Opouawe Canyons) exhibit a lower number of landslides and a concentration of landslides in the upper half of the canyon walls (Fig. 4); this may indicate that canyon downcutting may be a less important driver of landslides in this region, and that earthquakes may be more significant.

A second possible reason for landslide zonation is lithological control, reflecting the contrast between the deep, Late Cenozoic sedimentary basins located on the shelf, and the slope cover and Neogene turbidite sequences underlying the continental slope (Mountjoy et al. 2009; Uruski 1992). Landslide zonation may also be attributed to their retrogressive nature, with shallower landslides tending to be more numerous than deeper failures.

\subsection{Role of landslides in canyon evolution}

Bedrock landslides are numerous in the CS canyon system and they have an important influence in canyon evolution, predominantly in the form of wall erosion, lateral extension and dendritic network evolution. They have the potential to rapidly remove material from the continental slope and can affect up to a quarter of the canyon. Landslides represent a major cross-canyon source of material and an important process introducing material into canyon floors. As a result, landslide deposits may play an important role in the re-hierarchisation of canyon branches by blocking a canyon branch and favouring up-canyon infill. Area-frequency analyses show that the majority of the material is removed by small landslides (Fig. 3c); this contrasts with terrestrial environments, where most of the work tends to be carried out by moderately-sized landslides (Guthrie and Evans 2007). Axis-normal slope failures along canyon walls occur once the canyon floor has been excavated and the walls have been undercut, suggesting that bedrock landslides may become more important as the canyon matures; otherwise failure is initially restricted to the canyon head (Pratson and Coakley 1996). Bedrock mass failures can also affect adjacent slopes by removal of support, potentially leading to further destabilisation and retrogression. Landslides may also have an important role in gully initiation and development by generating the steep topography required for gully formation (Fig. 2b). The median slope gradients of both the headwalls and scars of the landslides are higher than the threshold of $5.5^{\circ}$ associated with gully initiation in the CS sector (Micallef and Mountjoy 2011) (Table 1). Gully formation can, in turn, also trigger landslides due to loss of support (Fig. 2b). 


\section{References}

Barnes PM, Audru JC (1999) Quaternary faulting in the offshore Flaxbourne and Wairarapa Basins, southern Cook Strait, New Zealand. New Zeal J Geol Geophys 42: 349-367.

Chaytor JD, Ten Brink US, Solow AR et al. (2009) Size distribution of submarine landslides along the U.S. Atlantic margin. Mar Geol 264: 16-27.

Chiswell SM (2000) The Wairarapa Coastal Current. New Zeal J Mar Fresh 34: 303-315.

Densmore AL, Anderson RS, McAdoo BG et al. (1997) Hillslope evolution by bedrock landslides. Science 275: 369-372.

Guthrie RH, Evans SG (2007) Work, persistence, and formative events: The geomorphic impact of landslides. Geomorphology 88: 266-275.

Hicks DM, Shankar U (2003) Sediment from New Zealand Rivers. NIWA.

Issler D, De Blasio FV, Elverhøi A et al. (2005) Scaling behaviour of clay-rich submarine debris flows. Mar Petrol Geol 22: 187-194.

Law CS, Nodder SD, Mountjoy JJ et al. (2010) Geological, hydrodynamic and biogeochemical variability of a New Zealand deep-water methane cold seep during an integrated three-year time-series study. Mar Geol 272: 189-208.

Micallef A, Berndt C, Masson DG et al. (2007) A technique for the morphological characterization of submarine landscapes as exemplified by debris flows of the Storegga Slide. J Geophys Res 112: F02001.

Micallef A, Mountjoy JJ (2011) A topographic signature of a hydrodynamic origin for submarine gullies. Geology 39: 115-118.

Mountjoy JJ, Barnes PM, Pettinga JR (2009) Morphostructure and evolution of submarine canyons across an active margin: Cook Strait sector of the Kikurangi Margin, New Zealand. Mar Geol 260: 45-68.

Pratson LF, Coakley BJ (1996) A model for the headward erosion of submarine canyons induced by downslope-eroding sediment flows. Geol Soc Am Bull 108: 225-234.

Stirling MW, McVerry GH, Berryman KR (2002) A new seismic hazard model for New Zealand. B Seismol Soc Am 92: 1878-1903.

Sultan N, Gaudin M, Berne S et al. (2007) Analysis of slope failure in submarine canyon heads: An example from the Gulf of Lions. J Geophys Res 112: F01009.

ten Brink US, Geist EL, Andrews BD (2006) Size distribution of submarine landslides and its implication to tsunami hazard in Puerto Rico. Geophys Res Lett 33: L11307-11311.

Uruski CI (1992) Sedimentary Basins and Structure of Cook Strait, 92/3. Inst Geol Nucl Sci, Lower Hutt, New Zealand.

Uruski CI (2010) New Zealand's deepwater frontier. Mar Petrol Geol 27: 2005-2026.

\section{Acknowledgments.}

This research was supported by Marie Curie Intra-European Fellowship PIEF-GA-2009-252702, Royal Society of New Zealand ISAT Fund, NIWA capability funding, FRST CEOC contracts, the HERMIONE EC project and the GRACCIE-CONSOLIDER (ref. CSD2007-00067) Spanish project. We are indebted to NIWA Ocean Geology technicians and the crew of RV Tangaroa for collecting the bathymetry data. AM, MC and GL belong to CRG on Marine Geosciences, supported by grant 2009 SGR 1305 of Generalitat de Catalunya). 